\title{
Variables affecting lipid oxidation in dried microencapsulated oils
}

\author{
Por Joaquín Velasco, Carmen Dobarganes and Gloria Márquez-Ruiz*
}

\author{
Instituto de la Grasa (CSIC). Avda. Padre García Tejero, 4 .- 41012-Sevilla (Spain)
}

\section{RESUMEN}

Variables que intervienen en la oxidación lipídica de aceites microencapsulados.

Los aceites microencapsulados son alimentos o ingredientes en polvo preparados mediante secado de emulsiones naturales 0 formula preparados món do formuladas, donde los glóbulos de aceite se encuentran dispersos en una matriz de hidratos de carbono y/o proteínas. El estudio de la oxidación lipídica en aceites microencapsulados es muy difícil ya que, además de las numerosas variables implicadas normalmente en la oxidación lipídica, principalmente el grado de insaturación, oxígeno, luz, temperatura, prooxidantes y antioxidantes, en estos sistemas lipídicos heterofásicos existen otros factores que ejercen una importante influencia. En este trabajo, se revisa la situación actual del conocimiento sobre oxidación lipídica en aceites microencapsulados en relación con las variables que intervienen específicamente en la oxidación de estos sistemas lipídicos. Concretamente, dichas variables incluyen las implicadas en el proceso de preparación (tipo y concentración de los componentes de la matriz y procedimiento de secado) y las relacionadas con las propiedades físico-químicas de los aceites microencapsulados (tamaño de partícula, tamaño de glóbulo de aceite, distribución lipídica, actividad del agua, $\mathrm{pH}$ e interacciones entre los componentes de la matriz).

PALABRAS-CLAVE: Aceites microencapsulados -- Antioxidantes - Oxidación lipídica - Sistemas lipídicos heterofásicos

\section{SUMMARY}

Variables affecting lipid oxidation in dried microencapsulated oils.

Dried microencapsulated oils are powdery foods or ingredients, prepared by drying natural or formulated emulsions, ingredients, prepared by drying natural or formulated emulsions, wherein the oil globules are dispersed in a matrix of saccharides
and/or proteins. The study of lipid oxidation in microencapsulated and/or proteins. The study of lipid oxidation in microencapsulated
oils is a very difficult task since, in addition to the numerous variables normally involved in lipid oxidation, mainly unsaturation degree, oxygen, light, temperature, prooxidants and antioxidants, other factors exert an important influence in these heterophasic lipid systems. In this paper, the present state of the art on lipid oxidation in dried microencapsulated oils is reviewed, focused on the variables specifically involved in oxidation of these lipid systems. Such variables include those pertaining to the preparation process (type and concentration of the matrix components and drying procedure) and those related to the physicochemical properties of microencapsulated oils (particle size, oil globule size, lipid distribution, water activity, $\mathrm{pH}$ and interactions between matrix components).

KEY-WORDS: Antioxidants - Heterophasic lipid systems Lipid oxidation - Microencapsulated oils.

\section{INTRODUCTION}

Dried microencapsulated oils are essentially powdery food products or ingredients constituted by oil globules dispersed in a continuous matrix of saccharides and/or proteins. The main purposes of oil microencapsulation are protecting sensitive oils from oxidation, masking or preserving flavors and aromas and transferring liquids into easily handled solids (Balassa and Fanger, 1971; Dziezak, 1988; Jackson and Lee, 1991; Matsuno and Adachi, 1993; Shahidi and Han, 1993; Gibbs et al., 1999). The process of oil microencapsulation consists basically of the preparation of an oil-in-water emulsion containing the matrix components in the aqueous phase, which is then dried, normally using spray-drying or freeze-drying techniques. The carbohydrates most commonly used as microencapsulating agents include lactose, maltodextrins, cyclodextrins, sucrose, gums, cellulose and maltose, whereas the main proteins used are casein, whey, gelatin, albumin and gluten.

Two types of microencapsulated oils may be distinguished, namely, formulated microencapsulated oils and dehydrated natural foods. Among the former, the most relevant ones are infant formulas (prepared with vegetable oils), flavoring additives and pigments (prepared with essential oils from fruits and spices), and microencapsulated fish oils, used as functional ingredients in a growing number of milk and bakery products, because of their beneficial physiological effects. Examples of dehydrated natural foods are milk powders, dried eggs and dehydrated soups and sauces.

Lipid oxidation in microencapsulated oils is of paramount importance because it results in loss of nutritional value and development of undesirable flavors in a wide range of commercialized food products. In general, the process of lipid oxidation leads to formation of a multitude of compounds of different molecular weight and polarity which makes it difficult to evaluate the degree of oxidation and the action of the numerous variables influencing lipid oxidation, such as unsaturation degree, oxygen, light, temperature, prooxidants and antioxidants (Frankel, 1993, 1998a, 1998b; Rossell, 1994; Frankel and Meyer, 2000). This situation becomes even more complicated in the case of microencapsulated oils, because additional factors of great relevance are involved, generally those derived from the heterogeneous lipid distribution and other physicochemical characteristics. However, few studies have 
Table I

Experimental conditions used in studies on oxidation of dried microencapsulated oils

\begin{tabular}{|c|c|c|c|c|}
\hline \multicolumn{4}{|c|}{ Experimental conditions } & References \\
\hline \multicolumn{5}{|c|}{ - Composition of dried microencapsulated oils: } \\
\hline \multicolumn{5}{|c|}{ a) Formulated dried microencapsulated oils } \\
\hline \multirow[t]{8}{*}{ - Lipid } & \multicolumn{2}{|c|}{ Model systems } & - Linoleic acid & $50,52,53,60,82,83,92,94$ \\
\hline & & & - Methyl linoleate & $50,63,76,81,107$ \\
\hline & & & - Others & $\begin{array}{l}38 \text { (oleic acid and triolein), } 50 \text { (methyl eicosapentaenoate), } 114 \text { (linolenic acid } \\
6 \text { (tridocosahexanoin) }\end{array}$ \\
\hline & Marine oils & & & $45,46,59,69,70,73,113,119,120,121,124$ \\
\hline & Seed oils & & & $27,89,95,119,121$ \\
\hline & Milk fat & & & $44,58,84,111$ \\
\hline & Pigments (C & otene & & $18,20,103$ \\
\hline & Orange oil & & & 3 \\
\hline \multirow[t]{15}{*}{ - Matrix } & \multicolumn{2}{|c|}{ Carbohydrates } & - Maltodextrins & $3,18,20,38,50,63,69,70,83,89,92,124$ \\
\hline & & & - Lactose & $18,45,46,59,63,73,107,119,120,121$ \\
\hline & & & - Cyclodextrins & $50,60,94,124,126$ \\
\hline & & & - Sucrose & $63,89,95,111$ \\
\hline & & & - Gums & $81,82,83,95$ \\
\hline & & & - Pullulan & $50,82,83,103$ \\
\hline & & & - Maltose or corn syrup & $27,44,124$ \\
\hline & & & - Cellulose & 38,70 \\
\hline & & & - Others & 52 (starch), 111 (flour) \\
\hline & \multirow{6}{*}{\multicolumn{2}{|c|}{ Proteins }} & - Sodium caseinate & $27,44,45,46,50,59,69,70,73,92,95,119,120,121$ \\
\hline & & & - Gelatine & $50,69,70,89,107$ \\
\hline & & & - Gliadin & 52,53 \\
\hline & & & - Whey & 58,84 \\
\hline & & & - Egg white & 113,114 \\
\hline & & & - Others & 76 (casein) , 50 (albumin) \\
\hline b) Commer & infant form & & & $2,4,35,36,39,93,102$ (prepared in lab), 116, 117, 118 \\
\hline c) Dehydrat & foods: & & Milk powders & $1,13,14,17,43,68,80,86,87,109,110,115,118$ \\
\hline & & & Egg powders & $41,42,48,67,85,123$ \\
\hline - Drying pr & edures: & & & \\
\hline a) Spray-dr & & & & $\begin{array}{l}1,3,4,14,18,20,27,39,41,42,43,44,48,52,53,58,59,67,69,70,80 \\
85,93,113,114,116,117,118,123,124\end{array}$ \\
\hline b) Freeze-d & & & & $\begin{array}{l}18,27,38,45,46,60,63,73,76,81,82,83,84,89,92,94,95,103,107 \\
110,113,119,120,121\end{array}$ \\
\hline c) Others & & & & hot-air drying (50, 81, 82, 83), foam-drying (115), drum-drying (19) \\
\hline - Evaluatio & f oxidation: & & & \\
\hline - Indices & & & ide value & $\begin{array}{l}1,27,39,44,52,53,60,68,89,93,111,113,114,116,118,119,123,124, \\
126\end{array}$ \\
\hline & & & & $4,17,35,39,73,109,111,116,123,124$ \\
\hline & & & gated dienes & $63,89,92,102,107,124$ \\
\hline & & & ne ratio & 69,73 \\
\hline & & $-\mathrm{Ot}$ & & 27 (carbonyl value), 45 (anisidine value) \\
\hline - Unoxidized & ubstrate & & & $8,20,41,42,44,50,52,53,81,82,92,103,113,117$ \\
\hline - Oxygen co & umption & & & $1,3,27,38,60,84,94,95,111$ \\
\hline - Volatiles & & & & $3,43,44,46,84,94,95,111$ \\
\hline - Sensory an & ysis & & & $3,27,58,59,80,109,115$ \\
\hline - Quantitatio & of oxidation & $\overline{-\mathrm{Cl}}$ & sterol oxides & $4,14,42,48,67,85,123$ \\
\hline & & & $\begin{array}{l}\text { zed triglycerides and } \\
\text { ric triglycerides }\end{array}$ & $45,73,119,120,121$ \\
\hline - Aminoacid & & & & $13,35,36,76,86$ \\
\hline - Tocophero & oss & & & $4,67,119,123$ \\
\hline - Fluorescen & & & & $36,68,87,102$ \\
\hline - Stability by & ancimat & & & $93,119,121$ \\
\hline - Free radica & & & & $2,109,110$ \\
\hline
\end{tabular}

See numbers in References. Among the publications cited, studies on oxidation of microencapsulated oils correspond to the following numbers: $1,2,3,4,13,14,17,19,20,27,35,36,38,39,41,42,43,44,45,46,48,50,52,53,58,59,60,63,67,68,69,70,73,76,80,81,82$, $83,84,85,86,87,89,92,93,94,95,102,103,107,109,110,111,113,114,115,116,117,118,119,120,121,124,126$. 
reported the variables involved in oxidation of microencapsulated oils and, furthermore, it is difficult to deduce general conclusions due to the great variety of matrixes and the different drying procedures used and, above all, the diversity of oxidation conditions and analytical methods applied to evaluate oxidation. To illustrate this, Table 1 lists the main experimental conditions used in the studies found on lipid oxidation of dried microencapsulated oils.

This review focuses on the most relevant variables influencing lipid oxidation in dried microencapsulated oils, which have been presented in two groups: first, those pertaining to the preparation process and second, those related to the physicochemical characteristics of these lipid systems. Also, a last point has been included to briefly revise those variables of general influence on lipid oxidation as examined in microencapsulated oils.

\section{INFLUENCE OF THE MANUFACTURING PROCESS PARAMETERS ON LIPID OXIDATION}

\subsection{Type and concentration of the matrix components}

The main point of interest regarding microencapsulated oils has undoubtedly been the influence of matrix characteristics on microencapsulation efficiency; that is, the percentage of encapsulated oil in total oil. The focus on microencapsulation efficiency is based on the assumption that the fraction of oil that remains free or unencapsulated after preparation of dried microencapsulated oils is theoretically more susceptible to oxidation than are the oil globules surrounded and hence protected by the matrix. Microencapsulation efficiency is evaluated indirectly by measuring the oil fraction accessible to extraction, also called surface, free or nonencapsulated oil, simply by washing with an organic solvent, usually hexane, under well-established conditions (Buma, 1971a; Sankarikutty et al., 1988). On the other hand, the oil fraction which requires previous disruption of the matrix for its extraction is considered to be the encapsulated oil.

A number of studies comparing the effectiveness of different proteins and carbohydrates as microencapsulating agents (Flink and Karel, 1970a; Kopleman et al., 1977; Bangs and Reineccius, 1990; Imagi et al., 1990, 1992; Young et al., 1993a, 1993b; Rosenberg and Young, 1993; Dian et al., 1996; Kim and Morr, 1996; Bhandari et al., 1998; Sheu and Rosenberg, 1998; Faldt and Bergenstahl, 1995; Keogh and O'Kennedy, 1999; Kim et al., 2000; Keogh et al, 2001), the influence of solid content in the previous emulsion (Rosenberg et al., 1990; Sheu and Rosenberg, 1995; McNamee et al., 1998; Pauletti and Amestoy, 1999; Chang and $\mathrm{Ha}, 2000$ ) and the effect of particle size and porosity of matrixes (Buma 1971a, b, c, d) on microencapsulation efficiency have been reported. Among them, there is considerable interest shown on the encapsulating properties of milk constituents for spray-dried powders (Young et al., 1993a, 1993b; Rosenberg and Young, 1993; Keogh and O'Kennedy, 1999; Sheu and Rosenberg, 1998; Fäldt and Bergenstahl, 1995). In the case of flavors most effective compounds for encapsulation are sodium caseinate (Dian et al., 1996, Kim and Morr, 1996), gums (Bangs and Reineccius, 1990) and $\beta$-cyclodextrin (Bhandari et al., 1998).

Linoleic acid and its derivatives have been extensively used as model encapsulated lipids to study the influence of matrix characteristics on oxidative deterioration. Using microencapsulated linoleic acid, the effectiveness of gliadin vs. starch in spray-dried powders (Iwami et al., 1987b) has been reported, as well as the cyclodextrin isomer of greater protective effect in freeze-dried powders (Reichenbach and Min, 1997; Kim et al., 2000), the efficacy of gum arabic as compared to pullulan and maltodextrin and the influence of the linoleic acid-to-polysaccharide ratio on the susceptibility to oxidation (Minemoto et al., 1999, 2001). In this context, Imagi and coworkers carried out an interesting study to test different saccharides and proteins for spray-drying microencapsulation of model lipids, namely, methyl linoleate, linoleic acid and ethyl eicosapentaenoate (Imagi et al., 1992). Unexpectedly, the encapsulating agents that had previously led to smaller globule size and greater encapsulation efficiency (Imagi et al., 1990) did not always retard oxidation (Imagi et al., 1992).

Among the studies using microencapsulated oils, an interesting approach was comparing oxidative stability of microencapsulated milkfat and bulk milkfat at the same surface-to-volume ratio (Moreau and Rosenberg, 1996). The authors prepared samples with whey proteins alone, or in combination with lactose, and showed clearly the protection conferred by the process of microencapsulation, but the results obtained by the different methods applied to evaluate oxidation were difficult for them to interpret. Studies comparing the efficacy of different carbohydrates showed that an increase in the dextrose equivalent improved the protective effect of maltodextrins in microencapsulated orange oil (Anandaraman and Reineccius, 1986), butter oil microencapsulated in flour was more resistant to oxidation than that in sucrose (Strange et al., 1997), seal blubber oil encapsulated in B-cyclodextrin resulted in longer storage stability than that in corn-syrup solids and maltodextrin (Wanasundara and Shahidi, 1995), and addition of lecithin and carboxymethyl cellulose to 
the formulation of a matrix of gelatin, caseinate and maltodextrin increased stability of microencapsulated squid oil (Lin et al., 1995a, b). Other authors investigated the protective effect of milk proteins, such as whey proteins for encapsulating milkfat (Moreau and Rosenberg, 1996; Keogh and O'Kennedy, 1999), sodium vs. calcium caseinate for encapsulating fish oil (Keogh et al., 2001) and milk proteins vs. soy proteins in infant formulas (Angulo et al., 1998).

\subsection{Drying procedure}

Among the drying techniques available for oil microencapsulation in the food industry, namely, spray-drying, spray cooling, spray coating, extrusion and freeze-drying (Jackson and Lee, 1991; Shahidi and Han, 1993), those more widely used are spray-drying and freeze-drying. Spray-drying is an economical and flexible process, consisting basically of atomization of the emulsion or dispersion into a heated gas stream, whereas the low temperatures used for freeze-drying make it especially suitable for volatiles and sensitive oils. In general, the influence of drying procedures on oxidative stability of microencapsulated oils has not been studied under conditions that permit establishment of comparisons, i.e., using the same process parameters and starting emulsions.

Some authors have reported that oxidation proceeded more rapidly in freeze-dried samples than in spray-dried samples, attributing such results to the greater surface area of the former (Fioriti et al., 1975; Taguchi et al., 1992a; Sims, 1994). Other researchers have found the opposite (Desobry et al. 1997; Stapelfeldt et al., 1999), even starting from samples with similar microencapsulation efficiency (Desobry et al. 1997), then attributing the lower oxidative stability of spray-dried samples to the high temperatures used during the atomization process. Minemoto and coworkers compared freeze-drying with hot-air drying at $50^{\circ} \mathrm{C}$, finding freeze-dried samples more resistant to oxidation even though they showed lower microencapsulation efficiency. Moreover, this research group suggested that the effect of the drying method might be closely related to the type of encapsulating agent and oxidative conditions. Thus, in a recent study testing the effect of drying methods and relative humidity on stability of linoleic acid encapsulated in either gum arabic, maltodextrin or pullulan, the poorest results were obtained for freeze-drying when using maltodextrin or pullulan under storage conditions of low or high relative humidity, but not at intermediate humidity or when using gum arabic at any humidity (Minemoto et al., 2001)

A study on freeze-drying of fish oils in lactose and sodium caseinate showed that increase in microencapsulation efficiency was inversely related to freezing rate (Heinzelmann et al., 2000a), consistent with results obtained in previous studies on retention of organic volatiles in mono-, di- and polysaccharides (Flink and Karel, 1970b; Menting et al., 1970; Rulkens and Thijssen, 1972). Other authors have observed marked differences between the microscopic characteristics of matrices obtained by slow and fast freezing, concretely in maltodextrinlinoleic acid based systems, where slow freezing led to a more porous and extended matrix as a result of a more complete crystal growth and phase segregation (Gejl-Hansen and Flink, 1977). Interestingly, Heinzelmann and coworkers found that the higher microencapsulation efficiencies obtained by lowering freezing rate or increasing homogenization pressure did not necessarily render higher oxidative stability (Heinzelmann et al., 2000a).

\section{INFLUENCE OF THE PHYSICO-CHEMICAL CHARACTERISTICS OF MICROENCAPSULATED OILS ON LIPID OXIDATION}

\subsection{Particle size}

Particle size in microencapsulated oils is very variable, depending mainly on the drying method used. It is generally accepted that an increase in particle size and, hence, a decrease in surface area would delay oxidation (Desobry et al.,1997), although the potential effect of changes in other parameters concurrent with modifications in particle size, e.g., in the content of surface oil, should not be ruled out (Fritsch, 1994).

\subsection{Oil globule size}

Even though measurement of oil globule size is a well-controlled characteristic of microencapsulated oils and usually is reported for starting samples, its influence on lipid oxidation has been studied very little. Theoretically, under the same conditions of air accessibility, as globule oil size increases, surfaceto-volume ratio decreases and thereby oxidation would be delayed. However, the effect of oil globule size alone is difficult to examine because, in most experiments, changes in oil globule size are accompanied by changes in microencapsulation efficiency.

As commented in point 2.1, Imagi and coworkers found that those microencapsulating agents leading to smaller oil globule sizes and higher microencapsulation efficiencies (Imagi et al., 1990) did not always retard oxidation (Imagi et al., 1992), and such results were unexpected on the basis that, theoretically, the encapsulated oil phase is more protected towards oxidation. Likewise, as noted (point 2.2), higher microencapsulation 
efficiencies and smaller oil globule sizes due to increases of homogenization pressure did not render higher oxidative stability (Heinzelmann et al., 2000a). Another observation in this context was pointed out by Ponginebbi and coworkers who attributed the less extensive oxidation found at high relative humidities in part to coalescence of oil droplets (Ponginebbi et al., 2000).

\subsection{Lipid distribution}

One important factor influencing oxidation in microencapsulated oils is the coexistence of two lipid phases. One is accessible to extraction with organic solvents, usually constituting a small portion of the total lipids, called free, surface or nonencapsulated oil. The other lipid phase is a noncontinuous phase, also known as encapsulated oil, wherein lipids are in droplets and whose extraction requires previous disruption of the matrix structure. When total lipids are obtained, it is not possible to deduce the real oxidation status of the encapsulated and surface oils, which may differ greatly in susceptibility to oxidation. For example, external oxidation (in the surface oil) might induce rancidity even if encapsulated oil has a low oxidation level. In such a case, rancid samples could show low level of oxidation as analyzed in total lipids. The opposite can also occur, i.e., even for a high total oxidation level, rancidity might not be detected until the oxidized encapsulated oil was released.

Furthermore, evolution of oxidation in the noncontinuous or dispersed lipid phase may become very complex since lipid droplets are isolated one from each other in the matrix and, consequently, different oxidation rates can occur in different droplets depending on the numerous variables already mentioned. However, once the encapsulated fraction has been extracted by disruption of the matrix, such differentiation is no longer possible since oil droplets are recovered as a continuous lipid phase.

The first challenge, that is, the study of the oxidation profile in surface and encapsulated oil phases, is not difficult considering that both fractions can be extracted separately. Even though, it is surprising that only a few researchers have studied oxidation in microencapsulated oils using this approach.

Some authors compared the oxidation of microencapsulated oils to that in the continuous lipid phase in mixtures constituted by the same components. Results indicated higher stability for the surface oil (Iwami et al., 1988) or the total oil (Taguchi et al., 1992a, 1992b) extracted from microencapsulates, as compared with their corresponding mixtures. However, the inverse also has been reported (Yoshii et al, 1997)
Geijl-Hansen and Flink tested triolein and oleic acid in a maltodextrin matrix and carried out separate extraction of both lipid phases only in initial samples. After storage of intact samples and those devoid of surface oil, initial elimination of the surface oil led to more stable samples (Geijl-Hansen and Flink, 1977). Other authors, using methyl linoleate encapsulated in an amorphous lactose-gelatine matrix, found that the surface oil, released as a consequence of lactose crystallization, oxidized more rapidly than did the encapsulated fraction (Shimada et al., 1991). Likewise, oxidation was more rapid in surface than in encapsulated oil in UV-exposed milkfat encapsulated in maltodextrin and sodium caseinate (Hardas et al., 2000). In another study, oxidation of linoleic acid in a sucrose-maltodextrin matrix was higher in the surface oil fraction than in the encapsulated oil, but there was discrepancy between the results obtained through determination of conjugated dienes and residual amount of unoxidized substrate (Ponginebbi et al., 2000).

Unfortunately, in some other studies it was not possible to establish clear differences in oxidation, because separation of phases was carried out only in initial samples (Lin et al., 1995a; Desobry et al., 1999; Orlien et al., 2000), or because determination of oxidation was exclusively applied to the surface oil fraction (Labrousse et al., 1992) or to the total lipids extracted (Minemoto et al., 1997). Other problems encountered have been due to the application of inappropriate analytical methods and/or rapid oxidation of the substrate used (Lin et al., 1995a).

Recently, we have directed our efforts to improve the evaluation of oxidation in microencapsulated oils during storage through separate extractions of surface and encapsulated oil fractions and application of an analytical methodology (Dobarganes et al., 1988; Márquez-Ruiz et al., 1996; Dobarganes et al., 2000) that enables concomitant quantitation of primary and secondary oxidation compounds (Márquez-Ruiz et al., 2000; Heinzelmann et al., 2000a; Velasco et al., 2000a; Velasco, 2001). Also, an accelerated oxidative test was applied to determine oxidative stability and evaluate efficiency of antioxidants (Velasco et al., 2000b). In our experience, it cannot be assumed that surface oil oxidation occurs more rapidly than that of the encapsulated oil fraction even though theoretically the former is not protected by the matrix and hence is more exposed to oxidation. In fact, the great number of variables influencing oxidation in these systems and the noncontinuous nature of the encapsulated oil phase exert a crucial role in the relative oxidation rate of both fractions. We have commonly observed in all samples analyzed that the oxidation profile of the surface fraction was very similar to that obtained for bulk oils (Martín-Polvillo et al., 1996, Martín-Polvillo, 2000) or oils extracted from fried potatoes (Pérez-Camino et al., 1991; Márquez-Ruiz et al., 
1999) and, thus, typical of lipids in a continuous phase, showing a clear end of the induction period as marked by initiation of polymerization and exhaustion of antioxidants. However, the oxidation profile of the noncontinuous phase or encapsulated oil was rather unusual, i.e., with high polymer values in samples containing high levels of tocopherol remaining, thus reflecting the coexistence of oil globules showing different oxidation rates. Therefore, by virtue of the analytical methods applied, we have been able to detect important differences in oxidation between continuous lipid phases (monophasic lipid systems) and noncontinuous lipid phases (Velasco, 2001).

\subsection{Water activity}

The effect of water activity in foods has been extensively studied by Karel and Labuza. In general, lipid oxidation is lowest at water activities close to the water monolayer, which falls between 0.2 and 0.3 for most foods, due to a decrease of the catalytic effect of transition metals, quenching of free radicals and singlet oxygen and/or retardation of hydroperoxide decomposition. However, the rate of lipid oxidation increases rapidly when the water activity is either decreased below or increased above the monolayer (Karel et al., 1967; Labuza, 1968, 1975). During manufacturing and storage, the quality of powdery foods may be affected by small changes within the low water activity range and hence, oxidative stability of such products at water activity values between 0.11 and 0.34 has been investigated in milk powders (Tamsma and Pallansch, 1964; Burvall et al., 1978; Stapelfeldt et al., 1997).

During the last years, a growing number of studies have focused on the effect of relative humidity $(\mathrm{RH})$ on oxidation of microencapsulated lipids (Desobry et al., 1997, 1999; Minemoto et al., 1997, 2001; Ponginebbi et al., 2000; Velasco, 2001). In the studies carried out by Minemoto and coworkers at $12,44,75$ and $96 \% \mathrm{RH}$, oxidation of linoleic acid encapsulated in gum arabic was dependent on $\mathrm{RH}$ at $37^{\circ} \mathrm{C}$, being higher as $\mathrm{RH}$ increased. This difference existed regardless of whether hot-air drying or freeze-drying was used. However, with either maltodextrin or pullulan as the encapsulating agent, samples prepared by freeze-drying were easily oxidized at low or high $\mathrm{RH}$. Ponginebbi et al. reported that oxidation was more rapid at 0 and $32 \%$ as compared to 43 and $75 \% \mathrm{RH}$ in linoleic acid encapsulated in sucrose and maltodextrin by freeze-drying and attributed this to sucrose crystallization at high moisture (Ponginebbi et al. 2000). Velasco examined the effect of $0 \%$ vs. $32 \% \mathrm{RH}$ in oxidation of surface and encapsulated fractions of sunflower and fish oils encapsulated in sodium caseinate and lactose by freeze-drying and found that dry conditions accelerated oxidation only in the surface oil (Velasco, 2001).

The effect of moisture content on physical changes of the solid matrix of microencapsulated oils may affect the oil distribution and, consequently, the accessibility of oxygen to the oil. After drying, a high-viscosity solid matrix in the glassy amorphous state is obtained, giving relative protection to the encapsulated oil (Orlien et al., 2000; Selim et al., 2000). However, when either moisture content or temperature increases the solid changes from the glassy state to another amorphous state, rubbery state, with a high molecular mobility. Temperature at the state change, called the glass transition temperature, depends on the solid matrix nature and decreases as water content increases (Roos et al., 1996). As molecular mobility increases by the plasticizing effect of water or by temperature, crystallization of sugars and/or the so-called "collapse" may occur (Orford et al., 1989; Levine and Slade, 1990; Chuy and Labuza, 1994). These physical changes are associated with the partial release of encapsulated lipids (Menting et al., 1970; Chirife and Karel, 1974; Gejl-Hansen and Flink, 1977 ; Kopelman et al., 1977; Rosenberg et al., 1990; Shimada et al., 1991) and the released oil then may be more exposed and undergo rapid oxidation (Karel, 1980; Shimada et al., 1991; Labrousse et al., 1992).

\section{5. $\mathrm{pH}$}

No references were found on the effect of $\mathrm{pH}$ on microencapsulated oils. The impact of $\mathrm{pH}$ on lipid oxidation is considered to be one important factor affecting oxidation in foods, because of its influence on the solubilization of transition metals, oxygen solubility and mobility, and on the rate of the nonenzymatic browning reaction (Fritsch, 1994).

\subsection{Interactions between matrix components}

The main reactions between matrix components, which may have relevant incidence on lipid oxidation in microencapsulated oils, are nonenzymatic browning or Maillard reactions. The resulting products from these reactions act as antioxidants (Karel, 1984, Eriksson, 1987). Alternatively, reactions between oxidized lipids and proteins may lead to loss of essential amino acids and hence impairment of nutritional value (Gardner, 1979; Karel, 1984; Eriksson, 1987; Hidalgo and Zamora, 2000; Frankel, 1998b).

Maillard reactions have been the subject of studies in milk powders, especially at water activities above that of the monolayer $(0.3-0.7)$ and at temperatures over $50^{\circ} \mathrm{C}$ (Karel, 1984; Nielsen et al., $1985)$. With respect to reactions between oxidized lipids and amino acids or proteins, a great number of 
studies have been reported on model systems subjected to high relative humidity, normally $80 \%$ or higher (Gardner, 1979), but results obtained are difficult to extrapolate to foods (Frankel, 1998b) and it is poorly understood how these reactions proceed in foods at low water activity. The only study found on microencapsulated oils that reported considerable losses of methionine, followed by those in tryptophan, hystidine and lysine, was carried out at $50^{\circ} \mathrm{C}$ and high relative humidity $(80 \%)$, using methyl linoleate encapsulated in casein and prepared by freeze-drying (Matoba et al., 1984). At low RH, methionine and lysine losses parallel to TBARS formation were detected in infant formulas under conditions of metal catalysis (Galdi et al., 1989), and loss of available lysine without any visible browning was found in lactose-hydrolyzed dried milk (Burvall et al., 1978).

\section{VARIABLES OF GENERAL INFLUENCE ON LIPID OXIDATION}

A brief overview is included of studies on microencapsulated oils focused on the effect of storage conditions, such as temperature, oxygen availability, light, etc. and on the action of antioxidants in these complex lipid systems.

\subsection{Storage conditions}

Most publications on the effect of storage conditions on oxidation of microencapsulated oils refer to shelf-life studies of dehydrated foods, such as milk powders and egg powders, and infant formulas. Oxidative deterioration of milk powders at ambient and higher temperatures have been investigated (Tamsma and Pallansch, 1964; Stapelfeldt et al., 1997; Nielsen et al., 1997; Liang, 2000), as well as the effect of packaging conditions (Tamsma and Pallansch, 1964; Hall et al., 1985; Min et al., 1989; Chan et al., 1993) and the influence of light (Ulberth and Roubicek, 1995; Choe and Cha, 1995), usually measuring headspace volatiles or cholesterol oxides., The effect of temperature and antioxidant addition has been evaluated in egg powders (Wahle et al., 1993; Huber et al., 1995; Guardiola et al., 1995, 1997; Li et al., 1996), via the analysis of cholesterol oxides. In infant formulas, special attention has been also placed on the effect of temperature (Giammaroli et al., 1997; Angulo et al., 1998). Also, the influence of the addition of polyunsaturated fatty acids on the oxidative stability of infant formulas during storage constitutes one of the subjects of growing interest (Thomkinson and Mathur, 1989, 1990; Presa-Owens et al., 1995).

\subsection{Antioxidants}

The action of antioxidants in microencapsulated oils has been investigated very little so far, and it is not predictable from the results obtained in bulk oils due to the particular characteristics of these complex lipid systems, e.g., the heterogeneous lipid distribution. Thus, as in other disperse systems such as emulsions, antioxidant activity may be strongly influenced by complex interfacial and phase distribution properties, according to their hydrophilic or lipophilic character (Frankel, 1998b; Frankel and Meyer, 2000; Velasco et al., 2002).

Addition of antioxidants provides a powerful means of enhancing oxidative stability of microencapsulated oils which are highly susceptible to oxidation. There is great interest in adding antioxidants to dried eggs (Morgan and Armstrong, 1987; Wahle et al., 1993; Guardiola et al., 1995, 1997; Huber et al., 1995), milk powders (Abbot, 1971; Hall et al., 1985; Stapelfeldt et al., 1999) and, especially, in infant formulas enriched with polyunsaturated fatty acids (Bendich and Brock, 1997) and microencapsulated fish oils (Heinzelmann et al., 2000a, b; Velasco et al., 2000a, b; Keogh et al., 2001). Tocopherols, ascorbyl palmitate and gallates are probably the most widely used antioxidants in these products. Also, some authors have investigated the antioxidant effect of certain amino acids on freeze-dried microencapsulated oils (Riisom et al., 1980), and others have used dried mixtures as model powders to test the antioxidant properties of proteins (Iwami et al., 1987a; Taguchi et al., 1988; Wang et al., 1991). However, the results obtained must be carefully interpreted because the antioxidant action depends greatly on the physical state of the substrate, conditions of oxidation, localization of antioxidants and the validity of the analytical methods employed to determine the extent and end-point of oxidation.

Lipid distribution should be considered when examining the effect of antioxidants in microencapsulated oils. As already commented, concurrency of high oxidation levels with high contents of remaining tocopherol in the extracted encapsulated oil could lead to misinterpretation of the efficiency of the antioxidant in this phase, when rather is a clear indication of the coexistence of oil globules showing different oxidation rates (Velasco et al., 2000a, 2000b, Velasco, 2001). The possible influence of other components of microencapsulated oils on antioxidant action also should be considered. For example, in iron-fortified infant formulas, ascorbic acid added because of its antioxidant effect in vivo, may act as prooxidant in the presence of non-protein-bound iron (Galdi et al., 1987; Almaas et al., 1997; Satué-Gracia et al., 2000).

\section{CONCLUDING REMARKS}

1. Lipid oxidation in microencapsulated lipids is of paramount importance because it may result in 
loss of nutritional value and development of flavors unacceptable to consumers in a significant number of products such as infant formulas, bakery products, milk powders, dried eggs or dehydrated soups and sauces.

2. As commented, it is difficult to foresee the rate of oxidation in heterogeneous systems due to the high number of variables involved. Particularly, evolution of oxidation in the noncontinuous or dispersed lipid phase may become very complex due to the heterogeneity in the lipid droplets isolated one from another in the matrix. Consequently, different oxidation rates can occur in different droplets. However, after extraction of the encapsulated fraction, a continuous oily phase is analyzed and substantial information on the oxidation in the different droplets is lost.

3. Much research remains to be done to increase knowledge of lipid oxidation in microencapsulated oils. Among others, the following aspects should be considered:

a) Development of analytical methods and extraction techniques for a better understanding of the evolution of oxidation in the lipids embedded in the matrix.

b) Definition of the relationships between chemical structure and efficacy of minor antioxidative compounds needed for successful protection of these lipid systems.

c) Studies clarifying the influence of physical properties such us globule size distribution, porosity, water activity, etc. on the rate of oxidation. This knowledge is essential for the selection of appropriate processing variables to obtain the most stable products.

\section{ACKNOWLEDGEMENT}

This study was funded by Ministerio de Ciencia y Tecnología (Project AGL 2001-0505). The authors thank Mercedes Giménez for assistance.

\section{REFERENCES}

1. Abbot, J. (1971) The effect of antioxidants on the keeping quality of spray-dried whole milk powder. $J$. Soc. Dairy Technol. 24: 182-183.

2. Almaas, R., Rootwell, T., Oeyasaeter, S. and Saugstad, O.D. (1997) Ascorbic acid enhances hydroxyl radical formation in iron-fortified infant cereals and infant formulas. Eir. J. Pedriat. 156: 488-492.

3. Anandaraman S. and Reineccius G.A. (1986) Stability of encapsulated orange peel oil. Food Technol. 40 (11): 88-93.

4. Angulo, A.J., Romera, J.M., Ramírez, M. and Gil, A. (1998) Effects of storage conditions on lipid oxidation in infant formulas based on several protein sources. $J$. Am. Oil Chem. Soc. 75: 1603-1607.

5. Balassa, L.L. and Fanger, G.O. (1971) Microencapsulation in the food industry. CRC Crit. Rev. Food Technol. July: 245-265.
6. Bangs, W.E. and Reineccius, G.A. (1990) Characterization of selected materials for lemon oil encapsulation by spray drying. J. Food Sci. 55: 1356-1358.

7. Bendich, A. and Brock, P.E. (1997) Rationale for the introduction of long chain polyunsaturated fatty acids and for the concomitant increase in the level of vitamin E in infant formulas. Int. J. Vitamin Nut. Res. 67: 213-231.

8. Bhandari, B.R., D'Arcy, B.R. and Bich, L.L.T. (1998) Lemon oil to $\beta$-cyclodextrin ratio effect on the inclusion efficiency of $\beta$-cyclodextrin and the retention of oil volatiles in the complex. J. Agric. Food Chem. 46: 1494-1499.

9. Buma, T.J. (1971a) Free fat in spray-dried whole milk 2. An evaluation of methods for the determination of free-fat content. Neth. Milk Dairy J. 25: 42-52.

10. Buma, T.J. (1971b) Free fat in spray-dried whole milk 8 . The relation between free-fat content and particle porosity of spray-dried whole milk. Neth. Milk Dairy J. porosity of spra $123-140$.

11. Buma, T.J. (1971c) Particle structure of spray-dried milk products as observed by a scanning electron microscope. Neth. Milk Dairy J. 25: 75-80.

12. Buma, T.J. (1971d) Free fat in spray-dried whole milk 3. Particle size. Its estimation, influence of processing parameters and its relation to free-fat content. Neth. Milk Dairy J. 25: 53-72.

13. Burvall, A., Asp, N.G., Bosson, A., San José, C. and Dahlqvist, A. (1978) Storage of lactose-hydrolysed dried milk: effect of water activity on the protein nutritional value. J. Dairy Res. 45: 381-389.

14. Chan, S.H., Gray, J.I., Gomaa, E.A., Harte, B.R. Kelly, P.M. and Buckley, D.J. (1993) Cholesterol oxidation in whole milk powders as influenced by processing and packaging. Food Chem. 47: 321-328.

15. Chang, P.S. and Ha, J.S. (2000) Optimization of fish oil microencapsulation by response surface methodology and its storage stability. Korean J. Food Sci. Technol. 32: 646-653.

16. Chirife, J. and Karel, M. (1974) Effect of structure descripting treatments on volatiles release from freeze-dried maltose. J. Food Technol. 9: 13-20.

17. Choe, E. and Cha, J. (1995) Oxidative stability of fat in milk powders. Agric. Chem. Biotechnol. 38: 259-262.

18. Chuy, L.E. and Labuza, T.P. (1994) Caking and stickiness of dairy-based food powders as related to glass transition. J. Food Sci. 59: 43-46.

19. Desobry, S.A., Netto, F.M. and Labuza, T.P. (1997) Comparison of spray-drying, drum-drying and freeze-drying for $\beta$-carotene encapsulation and preservation. J. Food Sci. 62: 1158-1162.

20. Desobry, S.A, Netto, F.M. and Labuza, T.P. (1999) Influence of maltodextrin systems at an equivalent 25DE on encapsulated beta-carotene loss during storage. J. Food Proc. Preserv. 23: 39-55.

21. Dian, N.L.H.M., Sudin, N. and Yusof, M.S.A. (1996) Characteristics of microencapsulated palm-based oil as affected by type of wall material. J. Sci. Food Agric. 70: 422-426.

22. Dobarganes, M.C., Pérez-Camino, M.C. and Márquez-Ruiz, G. (1988) High performance size exclusion chromatography of polar compounds in heated and non-heated fats. Fat Sci. Technol. 90: 308-311.

23. Dobarganes, M.C., Velasco, J. and Dieffenbacher A.(2000) The determination of polar compounds, polymerized triacylglycerols, oxidized triacylglycerols and diacylglycerols in fats and oils. Pure Appl. Chem. 72: 1563-1575. 
24. Dziezak J.D. (1988). Microencapsulation and encapsulated ingredients. Food Technol. 42: 136-151.

25. Eriksson, C.E. (1987) Oxidation of lipids in food systems, in "Autoxidation of unsaturated lipids". Ed. H.W.-S. Chan. Academic Press, Londres, pp. 207-231.

26. Faldt, P. and Bergenstahl, B. (1995) Fat encapsulation in spray-dried food powders. J. Am. Oil Chem. Soc. 72: 171-176.

27. Fioriti, J.A., Stahl, H.D., Cseri, J. and Sims, R.J. (1975). Chemical and organoleptic properties of dried emulsions. J. Am Oil Chem Soc 52: 395-399.

28. Flink, J. and Karel, M. (1970a) Retention of organic volatiles in freeze-dried solutions of carbohydrates. $J$. Agric. Food Chem. 18: 295-297.

29. Flink J. and Karel M. (1970b) Effects of process variables on retention of volatiles in freeze-drying. $J$. Food Sci. 35: 444-447.

30. Frankel E.N. (1993) In search of better methods to evaluate natural antioxidants and oxidative stability in
food lipids. Trends in Food Sci. Technol. 4: 220-225.

31. Frankel, E.N. (1998a) Methods to determine extent of oxidation, in "Lipid oxidation" Ed. E.N. Frankel, The Oily Press, Dundee, UK, pp. 79-98.

32. Frankel, E.N. (1998b) Foods, in "Lipid oxidation". Ed. E.N. Frankel, The Oily Press, Dundee, UK, pp. 187-225

33. Frankel, E.N. and Meyer, A.S. (2000) The problems of using one-dimensional methods to evaluate multifunctional food and biological antioxidants. J. Sci. Food Agric. 80: 1925-1941.

34. Fritsch, C.W. (1994) Lipid oxidation-the other dimensions. INFORM 5: 423-431.

35. Galdi, M., Carbone, N. and Valencia, M.E. (1989) Comparison of ferric glycinate to ferrous sulfate in model infant formulas: kinetics of TBA, lysine and methionine changes. J. Food Sci. 54: 1230-1233.

36. Galdi, M., Valencia, M.E. and Sambucetti, M.E. (1987) Changes in the physicochemical state of iron and nutritional deterioration in powdered infant formulas during storage Nutr. Rep Int 35: 1279-1284.

37. Gardner, H.W. (1979) Lipid hydroperoxide reactivity with proteins and amino acids: a review. J. Agric. Food Chem. 27: 220-229.

38. Gejl-Hansen F. and Flink J.M. (1977) Freeze-dried carbohydrate containing oil-in-water emulsions: microstructure and fat distribution. J. Food Sci. 42 1049-1055.

39. Giammarioli, S., Lammardo, A.M., Sanzini, E. and Bellomonte, G. (1997) Preliminary study on lipid oxidation in infant formulas during storage. Riv. Sci. Aliment. 26: 80-88

40. Gibbs, B.F., Kermasha, S., Alli, I. and Mulligan, C.N. (1999) Encapsulation in the food industry: a review. Int. J. Food Sci. Nutr. 50: 213-224.

41. Guardiola, F, Codony, R., Manich, A., Rafecas, M. and Boatella, J. (1995) Stability of polyunsaturated fatty acids in egg powder processed and stored under various conditions. J. Agric. Food Chem. 43 2254-2259.

42. Guardiola, F., Codony, R., Rafecas, M., Grau, A., Jordan, A. and Boatella, J. (1997) Oxysterol formation in spray-dried egg processed and stored under various conditions: prevention and relationship with other quality parameters. J. Agric. Food Chem. 45: 2229-2243.

43. Hall, G., Andersson, J., Lingnert, H. and Olofsson, B. 1985) Flavor changes in whole milk powder during storage. II. The kinetics of the formation of volatile oxidation products and other volatile compounds. J. Food Quality 7: 153-190.

44. Hardas, N., Danviriyakul, S., Foley, J.L., Nawar, W.W. and Chinachoti, P. (2000) Accelerated stability studies of microencapsulated anhydrous milk fat. Leb. Wiss. of microencapsulated

45. Heinzelmann, K., Franke, K., Velasco, J. and Márquez-Ruiz, G. (2000a) Microencapsulation of fish oil by freeze-drying techniques and influence of process parameters on oxidative stability during storage. Eur. Food Res. Technol. 211:234-239.

46. Heinzelmann, K., Franke, K Jensen, B and Haahr A.-M. (2000b) Protection of fish oil from oxidation by microencapsulation using freeze-drying techniques. Eur. J. Lipid Sci. Technol. 102 :114-121.

47. Hidalgo, F.J. and Zamora, R. (2000) The role of lipids in nonenzimatic browning. Grasas y Aceites 51: 35-49.

48. Huber, K.C., Pike, O.A. and Huber, C.S. (1995) Antioxidant inhibition of cholesterol oxidation in a spray-dried food system during accelerated storage. J. Food Sci. 60: 909-916.

49. Imagi, J., Kako, N., Nakanishi, K. and Matsuno, R (1990). Entrapment of liquid lipids in matrixes of saccharides. J. Food Engineering 12: 207-222.

50. Imagi, J., Muraya, K., Yamashita, D., Adachi, S. and Matsuno, R. (1992) Retarded oxidation of liquid lipids entrapped in matrixes of saccharides or proteins. Biosci. Biotech. Biochem. 56: 1236-1240.

51. Iwami, K., Hattori, M. and Ibuki, F. (1987a) Prominent antioxidant effect of wheat gliadin on linoleate peroxidation in powder model systems at high water activity. J. Agric. Food. Chem. 35: 628-631.

52. Iwami, K Hattori,M Nakatani, S and lbuki, $F$ (1987b) Spray-dried gliadin powders inclusive of linoleic acid (microcapsules): their preservability, digestibility and application to bread making. Agric. Biol. Chem. 51:3301-3307.

53. Iwami, K., Hattori, M., Yasumi, T. and lbuki, F. (1988) Stability of gliadin-encapsulated fatty acids against autoxidation. J. Agric. Food Chem. 36: 160-164.

54. Jackson, L.S. and Lee, K. (1991) Microencapsulation and the food industry. Lebensm.-Wiss.u.-Technol. 24 289-297.

55. Karel, M. (1980) Lipid oxidation, secondary reactions and water activity of foods, in "Autoxidation in foods and biological systems", Ed. H.G. Simic and M. Karel, Plenum Press, New York, pp. 191-206.

56. Karel, M. (1984) Chemical effects in food stored at room temperature. J. Chem. Education 61: 335-339.

57. Karel, M., Labuza, T.P. and Maloney, J.F. (1967) Chemical changes in freeze-dried foods and model systems. Cryobiology. 3: 288-296.

58. Keogh, M.K. and O'Kennedy, B.T. (1999) Milk fat microencapsulation using whey proteins. Int. Dairy J. 9: 657-663.

59. Keogh, M.K. O'Kennedy, B.T. Kelly, J. Auty, M.A Kelly, P.M., Fureby, A. and Haahr, A.-M. (2001) Stability to oxidation of spray-dried fish oil powder microencapsulated using milk ingredients. Food Chem Toxicol. 66: 217-224.

60. Kim, S.J., Park, G.B., Kang, C.B., Park, S.D., Yung, M.Y., Kim, J.O. and Ha, Y.L. (2000) Improvement of oxidative stability of conjugated linoleic acid (CLA) by microencapsulation in cyclodextrins. J. Agric. Food microencapsulation in

61. Kim, Y.D. and Morr, C.V. (1996). Microencapsulation properties of gum arabic and several food proteins: spray-dried orange oil emulsion particles. J. Agric. Food Chem. 44: 1314-1320. 
62. Kopelman, I.J., Meydav, S. and Wilmersdorf, P. (1977) Freeze-drying encapsulation of water soluble citrus aroma. J. Food Technol. 12: 65-72.

63. Labrousse S. Roos Y. and Karel M. (1992) Collapse and crystallization in amorphous matrices with encapsulated compounds. Sciences des Aliments 12 757-769.

64. Labuza T.P. (1968) Sorption phenomena in foods. Food Technol. 22: 15-24.

65. Labuza T.P. (1975) Sorption phenomena in foods: theoretical and practical aspects. In: "Theory, determination and control of physical properties of food determination and control of physical properties of fo
materials", ed., Reidel, Dordrecht C.K. RHA., p. 197.

66. Levine, H. and Slade, L. (1990) Influences of the glassy and rubbery states on the thermal, mechanical, and structural properties of doughs and baked products. In: "Dough Rheology and Baked Product Texture". Ed. AVI, New York. pp.157-330.

67. Li, S.X., Cherian, G. and Sim, J.S. (1996) Cholesterol oxidation in egg yolk powder during storage and heating as affected by dietary oils and tocopherol. $J$. Food Sci. 61: 721-725.

68. Liang, J.-H. (2000) Kinetics of fluorescence formation in whole milk powders during oxidation. Food Chem. 71: 459-463.

69. Lin, C.Ch Lin S.Y and Hwang, L.S. (1995a) Microencapsulation of squid oil with hydrophilic macromolecules for oxidative and thermal stabilization. J. Food Sci. 60: 36-39.

70. Lin, S.Y., Hwang, L.S and Lin, C.C. (1995b) Thermal analyzer and micro FT-IR/DSC system used to determine the protective ability of microencapsulated squid oil. J. Microencapsulation 12 (2): 165-172.

71. Márquez-Ruiz G., Jorge N., Martín-Polvillo M. and Dobarganes M.C. (1996) Rapid, quantitative determination of polar compounds in fats and oils by solid-phase extraction and exclusion chromatography using monostearin as internal standard. $J$. Chromatog. A 749: 55-60.

72. Márquez-Ruiz G. Martín-Polvillo $M$., Jorge, N., Ruiz-Méndez, M.V. and Dobarganes M.C. (1999) Influence of used frying oil quality and natural Influence of used frying oil quality and natural
tocopherol content on oxidative stability of fried tocopherol content on oxidative stability
potatoes. J. Am. Oil Chem. Soc. 76: 421-425.

73. Márquez-Ruiz, G., Velasco, J. and Dobarganes, M.C. (2000) Evaluation of oxidation in dried microencapsulated fish oils by combination of adsorption and size exclusion chromatography. Eur. adsorption and size exclusion

74. Martín-Polvillo, M. (2000) Evolución de la alteración oxidativa y formación de nuevos compuestos en sistemas modelo, aceites y alimentos grasos. PhD Thesis. Universidad de Sevilla.

75. Martín-Polvillo, M., Márquez-Ruiz, G., Jorge, N., Ruiz-Méndez, M.V. and Dobarganes, M.C. (1996) Evolution of oxidation during storage of crisps and
French fries prepared with sunflower oil and high oleic sunflower oil. Grasas y Aceites 47: 54-58.

76. Matoba, T., Yonezawa, D., Nair, B.M. and Kito, M. (1984) Damage to amino acid residues of proteins after reaction with oxidizing lipids: estimation by proteolytic enzymes. J. Food Sci. 49: 1082-1084.

77. Matsuno, R. and Adachi, S. (1993). Lipid encapsulation technology - techniques and applications to food. Trends in Food Sci. Technol. 41: 256-261.

78. McNamee, B.F., O'Riordan, E.D. and O'Sullivan, M. (1998) Emulsification and microencapsulation properties of gum arabic. J. Agric. Food Chem. 46 4551-4555.
79. Menting, L.C., Hoogstad, B. and Thijssen, H.A.C. (1970) Aroma retention during the drying of liquid foods. J. Food Technol. 5: 127-139.

80. Min, D.B., Lee, S.H., Lindamood, J.B., Chang, K.S and Reineccius, G.A. (1989) Effects of packaging conditions on the flavor stability of dry whole milk. $J$. Food Sci. 54: 1222-1224, 1245.

81. Minemoto Y., Adachi S. and Matsuno R. (1997) Comparison of oxidation of methyl linoleate encapsulated with gum arabic by hot-air-drying and freeze-drying. J. Agric. Food Chem 45: 4530-4534.

82. Minemoto, Y. Adachi, S and Matsuno, R. (1999) Autoxidation of linoleic acid encapsulated with polysaccharides of differing weight ratio. Biosci. Biotechnol. Biochem. 63: 866-869.

83. Minemoto, Y., Adachi, S. and Matsuno, R. (2001) Effect of relative humidity during storage on the autoxidation of linoleic acid encapsulated with a polysaccharide by hot-air-drying and freeze-drying. polysaccharide by hot-air-drying
Food Sci. Technol. Res. 7: 91-93.

84. Moreau D.L. and Rosenberg M. (1996) Oxidative stability of anhydrous milkfat microencapsulated in whey proteins. J. Food Sci. 61: 39-43.

85. Morgan, J.N. and Armstrong, D.J. (1987) Formation of cholesterol-5,6-epoxides during spray-drying of egg yolk. J. Food Sci. 52: 1224-1227.

86. Nielsen, H.K., DeWeek, D., Finot, P.A., Liarden, R. and Hurrell, R.F. (1985) Stability of tryptophan during food processing and storage. 1. Comparative losses of tryptophan, lysine and methionine in different model systems. J. Nutr. 53: 281-292.

87. Nielsen, B.R., Stapelfeldt, H., Skibsted, L.H. (1997) Differentiation between 15 whole milk powders in relation to oxidative stability during accelerated storage: analysis of variance and canonical variable analysis. Int. Dairy J. 7: 589-599.

88. Orford, P.O., Parker, R., Ring, S.G. and Smith, A.C (1989) Effects of water as a diluent on the glass transition behaviour of malto-oligosaccharides, amylose and amylopectin. Int. J. Biol. Macromol. 11: 91-96.

89. Orlien, V Andersen, A.B Sinkko, T and Skibsted L.H. (2000) Hydroperoxide formation in rapeseed oil encapsulated in a glassy food model as influenced by hydrophilic and lipophilic radicals. Food Chem. 68 191-199.

90. Pauletti, M.S. and Amestoy, P. (1999) Butter microencapsulation as affected by composition of wall material and fat. J. Food Sci. 64: 279-282.

91. Pérez-Camino, M.C., Márquez-Ruiz, G., Ruiz-Méndez, M.V. and Dobarganes, M.C. (1991) Lipid oxidation in fats and fatty foods. Quantitative determination of oxidized triglycerides, in "Proceedings of Euro Food Chem Vl", Vol. 2, Ed. W. Bultes, T. Ekland, R. Fenwick, W.

92. Ponginebbi, L., Nawar, W.W. and Chinachoti, P. (2000) Effect of relative humidity on lipid oxidation in freeze-dried emulsions. Grasas y Aceites 51: 348-354.

93. Presa-Owens, S., López-Sabater, M.C. and RiveroUrgell, M. (1995) Shelf-life prediction of an infant formula using an accelerated stability test (Rancimat). J. Agric. Food Chem. 43: 2879-2882.

94. Reichenbach W.A and Min D. B (1997) Oxidative stability and nuclear magnetic resonance analyses of linoleic acid encapsulated in cyclodextrins. J. Am. Oi Chem. Soc. 74: 1329-1333.

95. Riisom, T., Sims, R.J. and Fioriti, J.A. (1980) Effects of amino acids on the autoxidation of safflower oil in emulsions. J. Am. Oil Chem. Soc. 57: 354-359. 
96. Roos, Y.H., Karel, M. and Kokini, J.L. (1996) Glass transitions in low moisture and frozen foods: effects on shelf life and quality. Food Technol. 50 (11) 95-108.

97. Rosenberg, M. and Young, S.L. (1993) Whey proteins as microencapsulating agents. Microencapsulation of anhydrous milkfat-structure evaluation. Food Structure 12: 31-41.

98. Rosenberg, M., Kopelman, I.J. and Talmon, Y. (1990) Factors affecting retention in spray-drying microencapsulation of volatile materials. J. Agric. Food Chem. 38: 1288-1294.

99. Rossell, J.B. (1994) Measurements of Rancidity in "Rancidity of Foods". J.C. Allen and R.J. Hamilton (Ed.), Chapman \& Hall, Glasgow, pp. 22-53

100. Rulkens, W.H. and Thijssen, H.A.C. (1972). Retention of volatile compounds in freeze-drying slabs of maltodextrin. J. Food Technol. 7: 79-93.

101. Sankarikutty B., Sreekumar M.M., Narayanan C.S and Mathew A.G. (1988) Studies on microencapsulation of cardamon oil by spray-drying microencapsulation of cardamon oil by spray-d

102. Satué-Gracia, M.T., Frankel, E.N., Rangavajhyala, N. and German, J.B. (2000) Lactoferrin in infant formulas. Effect on oxidation. J. Agric. Food Chem. 48 4984-4990.

103. Selim, K. Tsimidou, M and Biliaderis, C.G. (2000) Kinetic studies of degradation of saffron carotenoids encapsulated in amorphous polymer matrices. Food Chem. 71: 199-206.

104. Shahidi, F. and Han, X.-Q. (1993) Encapsulation of food ingredients. Crit. Rev. Food Sci. Nutr. 33 501-547.

105. Sheu, T.-Y. and Rosenberg, M. (1995) Microencapsulation by spray-drying ethyl caprylate in whey protein and carbohydrate wall systems. J. Food Sci. 60: 98-103.

106. Sheu, T.-Y. and Rosenberg, M. (1998) Microstructure of microcapsules consisting of whey proteins and carbohydrates. J. Food Sci. 63: 491-494.

107. Shimada, Y., Roos, Y. and Karel, M. (1991) Oxidation of methyl linoleate encapsulated in amorphous lactose-based food model. J. Agric. Food Chem. 39. lactose-base

108. Sims, R.J. (1994) Oxidation of fats in food products. INFORM 5: 1020-1028.

109. Stapelfeldt, H., Nielsen, B.R. and Skibsted, L.H (1997) Effect of heat treatment, water activity and storage temperature on the oxidative stability of whole milk powder. Int. Dairy J. 7: 331-339.

110. Stapelfeldt, H., Nielsen, B.R., Jensen, S.K. and Skibsted L.H. (1999) Free radical formation in freeze-dried raw milk in relation to alpha-tocopherol level. J. Dairy Res. 66: 461-466.

111. Strange, E.D., Konstance, R.P., Lu, D., Smith, P.W. and Onwulata, C.I. (1997) Oxidative and functional stability during storage of butter oil encapsulated with sucrose or flour. J. Food Lipids 4: 245-260.

112. Taguchi, K., Iwami, K., Kawabata, M. and Ibuki, F. (1988) Antioxidant effects of wheat gliadin and hen's egg white in powder model systems: protection against oxidative deterioration of safflower oil and sardine oil. Agric. Biol. Chem. 52: 539-545.

113. Taguchi, K. Iwami, K. lbuk, F. and Kawabata, M (1992a) Oxidative stability of sardine oil embedded in spray-dried egg white powder and its use for $n-3$ unsaturated fatty acid fortification of cookies. Biosci. Biotech. Biochem. 56: 560-563.
114. Taguchi, K., Iwami, K., Ibuki, F. and Kawabata, M (1992b) Preservability and utilization of powdered $\alpha$-linoleic acid with egg white. Biosci. Biotech. Biochem. 56: 672-673.

115. Tamsma, A. and Pallansch, M.J. (1964) Factors related to the storage stability of foam-dried whole milk. IV. Effect of powder moisture content and in-pack oxygen at different storage temperatures. J. Dairy Sci. 47: 970-976.

116. Thompkinson, D.K. and Mathur, B.N. (1989) Corelation of chemical parameters for measurement of oxidation in PUFA rich dried food system. Indian $J$. oxidation in PUFA rich
Dairy Sci. 42: 659-660.

117. Thompkinson, D.K. and Mathur, B.N. (1990) Stability of fatty acids and nutritional adequacy of PUFA rich infant formula during storage. Indian J. Dairy Sci. $\mathbf{4 3}$ 203-206.

118. Ulberth, F. and Roubicek, D. (1995) Monitoring of oxidative deterioration of milk powder by headspace gas chromatography. Int. Dairy J. 5: 523-531.

119. Velasco, J. (2001) Ingredientes funcionales constituidos por aceites microencapsulados: evaluación de la oxidación lipídica y eficacia de antioxidantes en estudios de conservación y oxidación acelerada. PhD. Thesis. Universidad de Sevilla.

120. Velasco, J., Dobarganes, M.C. and Márquez-Ruiz, G. (2000a) Oxidation of free and encapsulated oil fractions in dried microencapsulated oils. Grasas y Aceites 51: 441-448.

121. Velasco, J., Dobarganes, M.C. and Márquez-Ruiz, G (2000b) Application of the accelerated test Rancimat to evaluate oxidative stability of dried microencapsulated oils. Grasas y Aceites 51: 261-267.

122. Velasco, J., Dobarganes, M.C ad Márquez-Ruiz, G. (2002) Oxidación en sistemas lipídicos heterofásicos: emulsiones aceite en agua. Grasas y Aceites 53: 239-247.

123. Wahle, K.W.J., Hoppe, P.P. and Mclntosh, G. (1993) Effects of storage and various intrinsic vitamin $E$ concentrations on lipid oxidation in dried egg powders. J. Sci. Food Agric. 61: 463-469.

124. Wanasundara, U.N. and Shahidi, F. (1995) Storage stability of microencapsulated seal blubber oil. $J$. Food Lipids 2: 73-86.

125. Wang, J.Y., Fujimoto, K., Miyazawa, T. and Endo, Y. (1991) Autoxidative mechanism of maize zein in powder model systems against methyl linoleate: effect of water activity and coexistence of antioxidants. J. Agric. Food Chem. 39: 351-355.

126. Yoshii, H., Furuta, T., Kawasaki, K., Hirano, H., Funatsu, Y., Toyomi, A. and Nakayama, S. (1997) Oxidative stability of powdery tridocosahexanoin included in cyclodextrin and its application to fish meal paste. Biosci. Biotech. Biochem. 61: 1376-1378.

127. Young, S.L., Sarda, X. and Rosenberg, M. (1993a) Microencapsulating properties of whey proteins. 1 Microencapsulation of anhydrous milk fat. J. Dairy Sci. 76: 2868-2877.

128. Young, S.L., Sarda, X. and Rosenberg, M. (1993b) Microencapsulating properties of whey proteins. 2. Combination of whey proteins with carbohydrates. $J$. Dairy Sci. 76: 2878-2885. 